B O U N A R E S A N CATEGORIES 

E D I T OR S

David B. Grusky stanford UNIVERSITY

Paula England STANFORD UNIVERSITY

EDITORIAL B OAR D

Hans-Peter Blossfeld

Mary C. Brinton

Thomas DiPrete

Michael Hout

Andrew Walder

Mary Waters 

BOUNDARIES AND CATEGORIES

Rising Inequality in Post-Socialist Urban China

\section{Wang Feng}

STANFORD UNIVERSITY PRESS

S T A N F OR D, C A L I F OR N I A

2008 
Stanford University Press

Stanford, California

(C2008 by the Board of Trustees of the Leland Stanford Junior University. All rights reserved.

No part of this book may be reproduced or transmitted in any form or by any means, electronic or mechanical, including photocopying and recording, or in any information storage or retrieval system without the prior written permission of Stanford University Press.

Typeset by Newgen in 10/14 Sabon

Library of Congress Cataloging-in-Publication Data

Wang, Feng.

Boundaries and categories : rising inequality in post-socialist urban China / Wang Feng.

p. cm.-(Studies in social inequality)

Includes bibliographical references and index.

ISBN 978-0-8047-5794-2 (cloth : alk. paper)

1. Equality-China. 2. China-Social conditions. 3.

China-Economic conditions. 4. Socialism-China. I. Title.

HN740.Z9S64655 2008

$305.0951-\mathrm{dc} 22$ 